\title{
HOGYHOGY NEM VAGYA FACEBOOKON? A Facebookot nem használók percepcióinak és motivációinak vizsgálata
}

\author{
Ujhelyi Adrienn - Domonkos Katalin \\ ujhelyi.adrienn@ppk.elte.hu - kati.domonkos@gmail.com
}

\begin{abstract}
Absztrakt
A közösségi oldalak közül a Facebook kiemelkedö szerepe tagadhatatlan: az oldal rendkívül népszerü hazánkban is, és nem csak a használat mértéke, de a kapcsolódó kutatások száma is exponenciálisan növekszik. Néhány kapcsolódó terület azonban eddig kevesebb figyelmet kapott, ilyen például a Facebook-ot nem használók, vagy az azt elhagyók motivációinak vizsgálata. Jelen kutatás e kérdés megválaszolására vállalkozik, két kérdöives kutatás keretében (1. Kérdöiv: N=167 nem használó, 2. Kérdöiv: N=156 használó). A nem használat leggyakoribb motivációi között szerepelt a félelem a függöségtöl, a közeggel kapcsolatos negatív attitüd, a társas motiváció hiánya, illetve adatbiztonsággal kapcsolatos aggályok.
\end{abstract}

\section{Kulcsszavak}

közösségi média, Facebook, nem használók, felhasználók, elhagyók, motiváció

\section{Adrien Ujhelyi - Katalin Domonkos \\ Research on the motivations of not using Facebook}

\begin{abstract}
Facebook is one of the most popular social networking sites; it is very popular in Hungary, too. Parallel to its use, the related research is also growing exponentially. However, while there have been many studies on users, until now little is known about those who do not use Facebook or after a time of use, quitted it. Our paper reports a survey on the motivations of non-using or quitting Facebook in Hungary. We applied two questionnaires for a sample of 167 non-users and 156 users. Among the most frequent motivations of not using Facebook we have found fear of addiction, general negative attitude toward the site, lack of social motivation and privacy issues.
\end{abstract}

\section{Keywords}

social media, Facebook, non-users, users, quitters, motivation 
A közösségi oldalak rövid időn belül kurrens közösségépítő, valamint vezető kommunikációs platformmá is váltak, melyek közül a Facebook kiemelkedő szerepe tagadhatatlan. Az oldal rendkívül népszerü hazánkban is, a Facebook penetráció aránya nálunk 46,19\%, ami 4.600 .000 felhasználót jelent. (Socialdaily 2015) Nem csak a használat, de a kapcsolódó kutatások száma is exponenciálisan növekszik. A közelmúltban több, a Facebook pszichológiai jellegü kutatásait áttekintő tanulmány is napvilágot látott, amelyek nem csak azt emelik ki, hogy a kapcsolódó kutatások elsősorban mely területekre koncentrálnak, hanem azt is, hogy mely témák kaptak eddig kevesebb figyelmet. (Anderson et al. 2012, Wilson et al. 2012, Caers et al. 2013, magyarul ld. Ujhelyi 2014) Ez utóbbiak kapcsán Caers és munkatársai úgy fogalmaznak, hogy „fontos lenne megértenünk, hogy a nem használók miért nem csatlakoznak, és hogy a korábbi használók miért törlik hozzáférésüket. Ez segítene rájönni, hogy melyek a Facebook (észlelt) hátrányai, hogy milyen kép él vele kapcsolatban az emberek fejében, és hogy hogyan fejlődhetnek tovább a közösségi hálózatok”. (Caers et al. 2012: 994)

További érveink is lehetnek a Facebookot nem használók kutatása mellett. Ellentétben más online aktivitással (pl. e-mail) a Facebook nem kompatibilis más hasonló platformokkal, vagyis az oldaltól való távolmaradás szociális aktivitások egész sorából zárja ki az egyént. (Baumer et al. 2013) Rengeteg kutatás mutatott rá arra is, hogy a Facebook számtalan pszichológiai szükségletet elégít ki (Wilson et al. 2012), ezért született meg az az elképzelés, hogy a Facebook nem használata kifejezetten átgondolt, tudatos döntés eredménye is lehet. Portwood-Stacer (2012) például úgy fogalmaz, hogy a Facebook elutasítása úgy is felfogható, mint a fogyasztói társadalommal szembeni ellenállás egyik kifejezési módja. Okfejtése szerint a Facebook visszautasítása tükröz egy bizonyos fokú kulturális és technológiai tőkét is, a döntési szabadsággal rendelkező nem használók emiatt is hangoztatják lelkesen a nem használat melletti tudatos és átgondolt érveiket a médiában, ezzel mintegy elhatárolódva azoktól, akik társadalmilag hátrányos helyzetük vagy anyagi okok miatt nem használják azt. Ez egyrészt értékkifejezés, a mainstreammel szembeni felsőbbrendűség, a nárcizmus és a felszínesség elutasítása, másrészt én-kifejező funkciót is betölt, gyakran identitásukat demonstrálják a nem használattal.

Jelen kutatásban arra vállalkozunk, hogy egy kérdőíves felmérés keretében vizsgáljuk meg e döntések hátterét, elsősorban a platformmal kapcsolatos attitüdökre, a nem használat okaira, illetve a használókkal és a nem használókkal kapcsolatos sztereotípiákra fókuszálva.

\section{Facebookot nem használók a kutatások tükrében}

\section{Használók és nem használók összehasonlítása}

A kapcsolódó kutatások egy része a használók és nem használók közötti különbségeket és azonosságokat kívánta feltárni. Az egyik első ilyen vizsgálat (Hargittai 2008) több közösségi média platformot hasonlított össze, kifejezetten felhívva a figyelmet arra, hogy a használat (és a nem használat) jellegzetességei és indítékai jelentősen eltérhetnek. Ez az amerikai kutatás leginkább a szociodemográfiai jellegzetességekre koncentrált, eredményei szerint a Facebook esetében a kor, a nem, a spanyol ajkúság, a szülők iskolai végzettsége, a lakóhely típusa és az internet-hozzáférés bírt prediktív erővel. 2008-ban tehát a Facebookot használók fiatalabbak voltak a nem használóknál, több nő volt közöttük, a spanyol ajkúak kevésbé használták (ők inkább a MySpace-t preferálták), a szüleik iskolai végzettsége magasabb volt, jellemzően a szüleikkel laktak és volt internet-előfizetésük.

Tufekci (2008) vizsgálata finomítja a fenti eredményeket. A demográfiai jellegzetességeket tekintve eredményei összecsengenek Hargittai konklúziójával, a nem használók között kevesebb a nő és a fiatalabb. A szerző kérdőíves és interjús eredményeiből leszürhetö legföbb tanulságnak azt tartja, hogy a közvélekedéssel ellentétben a nem használók nem tartják veszélyesebbnek az online közeget, mint a használók és nem nevezhetők szociális értelemben 
izoláltnak. Van viszont egy tendenciózus különbség a két csoport között: a közösségi oldalakat nem használók internethasználatát a praktikum jellemzi, szemben az ilyen oldalakat is használók szociálisabb és expresszívebb használatával. A nem használók többször megfogalmazták, hogy nem kíváncsiak különösebben a többi ember életére, idő-elvesztegetésnek érzik azt. Erre a csoportra továbbá jellemző, hogy hasonló mennyiségü közeli barátról számolnak be, mint a használók, de kevésbé rendszeresen tartják velük a kapcsolatot.

Sheldon 2012-es kutatása során a használók és a nem használók között további személyiségtényezőbeli különbséget talált. A nem használók szignifikánsan alacsonyabb pontszámot értek el az élménykeresés, a gátlástalanság és az unalomra való fogékonyság skálákon. A kutatók kevésbé találták őket szociálisan aktívnak, félénkebbek és magányosabbak voltak, mint a használók. (Sheldon 2012)

Ryan és Xenos 2011-es kutatása is a személyiségtényezőkre és a jellemző aktivitásokra koncentrált. Azt találták, hogy a Facebook használók magasabb pontszámot értek el az extraverzió, a totális nárcizmus, valamint az exhibicionizmus skálákon, valamint a magány skála ún. családi magányosság alskáláján, mint a nem használók. A nem használók pontszáma magasabb volt a félénkség és a szociális magányosság skálán. Eredményeik szerint a napi Facebook használat mennyisége összefüggést mutat a neuroticizmussal és negatív korrelációt a lelkiismeretességgel. (Ryan és Xenos 2011)

Ljepava és munkatársai kanadai egyetemisták két csoportját hasonlították össze, akik Facebook használatuk alapján a két véglethez tartoztak, vagy gyakran használták (napi két órát vagy többet) vagy egyáltalán nem. Legérdekesebb eredményük talán az, hogy míg a gyakori használók a nyílt nárcizmus skálán, a nem használók a rejtett nárcizmus skálán értek el magasabb pontszámot. (Ljepava et al. 2013) A gyakori használókra továbbá magasabb önfeltárási motiváció is jellemző volt. A nem használók kevesebb közeli - akár online, akár offline - barátról számoltak be.

\section{A nem használat mögötti motivációk}

A kutatások másik része a nem használat okait igyekezte feltérképezni. A vizsgálatok kérdőívek és interjúk segítségével számtalan indokot azonosítottak, a szakirodalmat áttekintve az alábbi nagyobb kategóriák körvonalazódnak.

1. Alternativák preferálása - A Facebook helyett más közösségi oldal, vagy kommunikációs csatorna (MSN, Google+, LinkedIn, Twitter...) preferálása. (Baker és White 2011, Turan et al. 2013)

2. Adatvédelem - szinte minden kutatásban felmerül az adatvédelemmel kapcsolatos problémák miatti távolmaradás, a félelem az adatokkal való visszaéléstöl. (pl. Turan et al. 2013; Baumer et al. 2013, Lampe et al. 2013) Többen beszámoltak arról, hogy nem szívesen osztanak meg magukról dolgokat. (Baker és White 2011) Egy interjúalany úgy fogalmazott, hogy a Facebookon lenni olyan, mint egy „globális akváriumban” élni. (Baumer et al. 2013)

3. Motiváció hiánya, időpazarlás - szintén a leggyakrabban említett okok között volt az, hogy a facebookozást időpazarlásnak, unalmasnak, érdektelennek, határozottan nem hasznos időtöltésnek gondolták (Turan et al. 2013, Baker és White 2011, Lampet et al. 2013), illetve a válaszadók gyakran kifejezték a mások élete iránti közömbösségüket. (Turan et al. 2013)

4. Félelmek - mások épp ellenkezőleg, a túlzott használattól féltették magukat, attól, hogy a platform használata függőséghez vezethet (Baumer et al. 2013; Turan et al. 2013), ronthatja a teljesítményt (Baumer et al. 2013, Lampe et al. 2013), következményei között akár online zaklatás is szerepelhet (Baker és White 2011, Baumer et al. 2013), vagy párkapcsolati problémákat okozhat. (Baumer et al. 2013) 
5. Külső okok - többen külső kényszereket vagy indokokat említettek: családi, szülöi aggályokat (Baker és White 2011, Turan et al. 2013) munkahelyi szabályozást (Turan et al. 2013, Baumer et al. 2013), szülői korlátozást (Baker és White 2011), a partnerük rosszallását (Baumer et al. 2013), barátaik példáját (Baker és White 2011), esetenként vallási elöírásokat. (Rainer et al. 2013)

6. Közeggel szembeni ellenérzések - többen megfogalmazták negatív véleményüket specifikusan a Facebookról vagy általánosan az online közegről. Ezek szerint a Facebook mára eltért eredeti közösségépítő céljától (Turan et al. 2013), és önkényesen változtatja az adatvédelmi beállításokat. (Baumer et al. 2013) Mások azt hangsúlyozzák, hogy nem hisznek a virtuális barátságokban és az online közeg csökkenti a kommunikáció minőségét. (Turan et al. 2013, Lampe et al. 2013) Baumer (2013) kutatási eredményei alapján azt fogalmazza meg, hogy a Facebookot nem használók válaszaiban többször érezhető volt egyfajta büszkeség és lázadás. Lampe és munkatársai cikkükben egy nem-használó válaszát idézik: „Én jól érzem magam a börömben, nincs szükségem 8000 'barátra'”. (Lampe et al. 2013: 6.)

\section{Az elhagyók}

A nem használókon belül kiemelt alcsoportként kezelhetők az elhagyók, vagyis azok, akik korábban regisztráltak, de átmenetileg vagy végleg törölték, illetve deaktiválták profiljukat. Ezt a tevékenységet virtuális identitás öngyilkosságnak (Stieger et al. 2013) vagy egyszerüen digitális öngyilkosságnak (Karppi, 2011) is nevezik. Rainie (Rainie et al. 2013) adatai szerint a jelenlegi Facebook használók 61\%-a legalább egyszer egy időre elhagyta az oldalt. Ami különösen érdekessé teszi a jelenséget, az a mozgalom jellege. 2010. máj. 31-ét például „Quit Facebook Day"-nak nevezték ki, ez lett a szimbolikus dátuma a Facebookról kilépésnek. A kampány során arra kérték a felhasználókat, hogy a platform felhasználókat kihasználó müködése miatti tiltakozásul töröljék profiljukat. (Végül több mint 40.000-en jelezték ez irányú szándékukat, azt persze nem lehet tudni, hogy közülük hányan tették meg valójában.) Léteznek olyan oldalak ${ }^{1}$, melyeket kifejezetten azért hoztak létre, hogy segítsék a digitális öngyilkosságot (ma már egyik sem müködik).

Stieger és munkatársai (2013) a jelenleg is Facebook használókat az elhagyókkal vetették össze, több szignifikáns különbséget találva. Utóbbi csoport magasabb pontszámot ért el az internetaddikciós skálán, lelkiismeretesebbnek bizonyult a használóknál, illetve inkább jellemezték adatvédelemmel kapcsolatos aggodalmak. A Facebookot elhagyók miértre vonatkozó válaszainak kvalitatív elemezése után öt tipikus okot azonosítottak (az említés gyakorisága szerinti sorrendben): (1) adatvédelemmel kapcsolatos aggályok, (2) egyéb motivációk (pl. spamek, zaklatás), (3) a Facebookkal kapcsolatos általános elégedetlenség, (4) negatív társas aspektusok (pl. kommunikációs kényszer, felszínes beszélgetések, nem valódi barátok) és (5) addikciótól való félelem. Rainie és munkatársai (2013) olyan embereket kérdeztek meg, akik rövidebb-hosszabb szünetet tartottak a Facebook használatában. Közülük legtöbben időhiányt (21\%) vagy érdektelenséget (10\%) emlegettek. Tizedük időelvesztegetésnek élte meg, $9 \%$-uk szerint pedig túlságosan sok volt a „dráma”, konfliktus és pletyka. További indokok között szerepelt az, hogy túl sok időt foglalt le, valamint az unalom, az adatvédelmi aggályok és más alternatívák használata is.

Dindar és Akbulut (2014) kutatása egy speciális populációt vizsgált - tanárjelölteket (pre service teachers) - összehasonlítva a véglegesen és az átmenetileg kilépőket. Kérdőíves kutatásuk alapján négy fő kategóriát azonosítottak: külső, személyes, gyakorlati okok, valamint az észlelt hasznosság. Interjúalanyaik az alábbi motivációkat sorolták fel: időpocsékolás, zavaró

\footnotetext{
${ }^{1}$ Például a seppukoo.com vagy a suicidmachine.com.
} 
hatások, párkapcsolati nyomás, érdeklődés hiánya, adatvédelmi megfontolások, és szakítás feldolgozása. Nem meglepő módon a csak átmenetileg kilépők hasznosabbnak látták a platformot, mint a véglegesen kilépők.

Mivel magyar nyelven nem találtunk a témában releváns cikket, hasznosnak gondoltuk a kapcsolódó szakirodalmat egy táblázatban összefoglalni. (1. táblázat)

1. táblázat

A nem használattal kapcsolatos szakirodalom összegzése

\begin{tabular}{|c|c|c|}
\hline Szerzők & A kutatás fókusza & Minta \\
\hline $\begin{array}{l}\text { Ryan és } \\
\text { Xenos } 2011\end{array}$ & $\begin{array}{l}\text { Használók és nem használók közti kü- } \\
\text { lönbségek } \\
\text { - személyiségtényezők } \\
\text { - preferált funkciók }\end{array}$ & $\begin{array}{l}1158 \text { ausztrál FB használó és } \\
166 \text { nem-használó (18-44 év) }\end{array}$ \\
\hline $\begin{array}{l}\text { Ljepava et al. } \\
2013\end{array}$ & $\begin{array}{l}\text { Facebookot gyakran használók és nem } \\
\text { használók összehasonlítása }\end{array}$ & $\begin{array}{l}70 \text { kanadai gyakori használó és } \\
36 \text { nem-használó (18-42 év) }\end{array}$ \\
\hline $\begin{array}{l}\text { Hargittai } \\
2008\end{array}$ & $\begin{array}{l}\text { Facebookot használók és nem haszná- } \\
\text { lók összehasonlítása }\end{array}$ & $\begin{array}{l}835 \text { használó és } 225 \text { nem-hasz- } \\
\text { náló (18-29 év) }\end{array}$ \\
\hline $\begin{array}{l}\text { Turan et al. } \\
2013\end{array}$ & $\begin{array}{l}\text { A nem használat motivációinak feltárá- } \\
\text { sa kvalitatív módszerrel }\end{array}$ & 20 török nem-használó (18-25 év) \\
\hline $\begin{array}{l}\text { Baker és } \\
\text { White } 2011\end{array}$ & $\begin{array}{l}\text { A nem használat motivációinak feltá- } \\
\text { rása }\end{array}$ & $\begin{array}{l}69 \text { ausztrál nem-használó (13-18 } \\
\text { év) }\end{array}$ \\
\hline $\begin{array}{l}\text { Baumer et al. } \\
2013\end{array}$ & Facebooktól való visszalépés motivációi & $\begin{array}{l}226 \text { használó és } 184 \text { átmenetileg } \\
\text { vagy véglegesen nem használó } \\
\text { (19-76 év) }\end{array}$ \\
\hline Tufekci 2008 & $\begin{array}{l}\text { Használók és nem használók összeha- } \\
\text { sonlítása }\end{array}$ & $\begin{array}{l}443 \text { amerikai közösségi oldal } \\
\text { használó és } 86 \text { nem használó } \\
\text { (egyetemi hallgatók) }\end{array}$ \\
\hline $\begin{array}{l}\text { Dindar és } \\
\text { Akbulut } 2014\end{array}$ & $\begin{array}{l}\text { Nem használó tanárjelöltek motivációi- } \\
\text { nak feltárása kvantitatív és kvalitatív } \\
\text { módszerrel }\end{array}$ & $\begin{array}{l}231 \text { végleges vagy időszakosan } \\
\text { elhagyó török tanárjelölt (átlag- } \\
\text { életkor } 20 \text { év) }\end{array}$ \\
\hline $\begin{array}{l}\text { Rainie, Smith } \\
\text { és Duggan } \\
2013\end{array}$ & Facebook elhagyásának okai & $\begin{array}{l}316 \text { amerikai szünetet tartó fel- } \\
\text { használó }\end{array}$ \\
\hline Sheldon 2012 & $\begin{array}{l}\text { Használók és nem használók összeha- } \\
\text { sonlítása }\end{array}$ & $\begin{array}{l}283 \text { használó és } 44 \text { nem hasz- } \\
\text { náló (19-76 év) }\end{array}$ \\
\hline $\begin{array}{l}\text { Portwood- } \\
\text { Stacer } 2012\end{array}$ & $\begin{array}{l}\text { Nem használók interjúinak diskurzus- } \\
\text { analízise }\end{array}$ & 20 nem használó \\
\hline $\begin{array}{l}\text { Stieger et al. } \\
2013\end{array}$ & $\begin{array}{l}\text { Facebook használók és elhagyók össze- } \\
\text { hasonlítása }\end{array}$ & $\begin{array}{l}321 \text { használó és } 310 \text { elhagyó (11- } \\
75 \text { év) }\end{array}$ \\
\hline $\begin{array}{l}\text { Lampe et al. } \\
2013\end{array}$ & $\begin{array}{l}\text { Facebook használók és nem használók } \\
\text { összehasonlítása, a nem használat moti- } \\
\text { vációi }\end{array}$ & $\begin{array}{l}480 \text { használó és } 134 \text { nem hasz- } \\
\text { náló (átlagéletkor } 46,3 \text { év) }\end{array}$ \\
\hline
\end{tabular}




\section{A kutatás célkitüzései és kérdései}

1. Jelen kutatás egyik célja a Facebook nem használat motivációs hátterének feltárása. Ez egyrészt lehetőséget ad a nemzetközi szakirodalomban talált eredményekkel való összehasonlításra, másrészt lehetővé teszi a különböző csoportok indokainak összevetését. Ilyen csoportok lehetnek a különböző korosztályok, illetve a sohasem csatlakozók és a kilépők, valamint talán érdemes a két nem motivációit is összehasonlítani.

2. A nem használat motivációinak mélyebb megértéséhez fontos lehet annak felmérése, hogy a korábban már regisztráltak milyen élmények hatására hagyták abba a használatot. Kiegészítheti továbbá a képet, ha feltárjuk, milyen alternatív közösségi média-felületeket használnak a Facebookot nem használók, és milyen okból.

3. Feltételezések szerint a nem használat motivációi között megtalálhatóak a Facebookot használókkal kapcsolatos attitüdök. Ennek érdekében mind használókat, mind nem használókat kérdeztünk a másik csoporttal kapcsolatos percepciójáról. A szakirodalomban ugyan nem találkoztunk hasonló fókuszú kutatással, de az igény már felmerült, Baumer (2013) például azt írja, hogy a Facebook profillal rendelkezök egyszerre tekintenek a nem használókra meg nem értéssel és tisztelettel. A jövőben érdemes lenne a percepciókat is megvizsgálni - folytatja.

4. A nem használók nem alkotnak homogén csoportot, „,nincs prototipikus nem-használó, különféle jellegzetességekkel és motivációval rendelkeznek" (Stieger et al. 2013: 632.) A motivációk alapján elvégzett klaszteranalízis segítségével megpróbáljuk a nem használók különböző csoportjait azonosítani és profiljukat felrajzolni.

\section{Minta és módszer}

A kutatást pilot interjúk felvétele ${ }^{2}$ előzte meg, melyek célja elsősorban az volt, hogy a felmerülő válaszok segítséget nyújtsanak egy kérdőív kidolgozásához. Az interjú kérdései főleg a motivációk feltárására, a kommunikációs alternatívák, illetve az elhagyók esetében a korábbi esetleges negatív élmények azonosítására irányultak. Interjúalanyaink összesen hatan voltak, 4 férfi és 2 nő, átlagéletkoruk 44,2.

Az interjúk során felmerült szempontok, valamint a szakirodalom alapján két kérdőívet hoztunk létre.

\section{1. kérdőív}

Az első kérdőív kifejezetten a nem használóknak szólt. Az alapvető szociodemográfia adatokon túl nyitott kérdések vonatkoztak az esetleges korábbi használatra és a profil törlésének vagy deaktiválásának okára, illetve a nem használat észlelt hátrányai. A kérdőív tartalmazott továbbá zárt kérdéseket is: 25 motivációra vonatkozó itemet, rákérdeztünk az alternatív közösségi oldalak használatára, és két - ugyanazt a - 22 tulajdonságpárt felsoroló szemantikus differenciál skála formájában arra kértük a kitöltőket, hogy jellemezzék a nem használókat és a használókat is. Ezen kívül 11 állítás formájában a platformmal, illetve a használókkal és a nem használókkal kapcsolatos általános nézeteket soroltuk fel, felkérve a kitöltőket egyetértésük fokának kifejezésére. A kérdöívvel összesen 167 személyt sikerült elérnünk, 88 nőt és 78 férfit, átlagéletkoruk 39,2 év volt (18-77 év között). ${ }^{3}$

${ }^{2}$ Az interjúk felvételében, illetve az adatgyüjtés további részében nyújtott segítségéért szeretnénk köszönetet mondani Erdélyi Zitának és Kozma Máriának.

3 A nem használóknak az általunk megcélzott köre nem egy jól elérhető populáció, kifejezetten nehéz volt elérni a fenti mintaelemszámot. Érdekességképp kiszámoltuk az általunk a szakirodalomban fellelt összes kvantitatív vizsgálat mintanagyságát, az átlaguk éppen 167 fö. 


\section{2. kérdő́ív}

A másik kérdőív a Facebookot használók nem használókkal és saját csoportjukkal kapcsolatos percepcióit mérte, ugyanazon kérdések segítségével. A demográfiai kérdések mellett kérdeztük őket Facebook használatukról (mikor regisztrált, hány ismeröse van), nyitott kérdéseket tettünk fel az oldallal kapcsolatos esetleges negatív élményeiröl, illetve, hogy szüneteltette-e már a profilját. Ezen kívül az előző kérdőívben használt kétszer 22 tulajdonságpárt és az ott szereplő 11 itemet tartalmazta a kérdöív. A minta összesen 156 főből állt, ebből 114 nő és 42 férfi, átlagéletkor 28,2 (18-62 év között). A statisztikai feldolgozás során a nemi kiegyensúlyozatlanságot egy post hoc súlyozási módszerrel egyenlítettük ki (50-50\%).

\section{Eredmények}

Mindenekelőtt az adatok előkészítéséhez kezdtünk hozzá, az életkor alapján két korosztályi kategóriát hoztunk létre: a 18-34 közöttiek $(\mathrm{n}=84)$ alkották az egyik, és az ennél idősebbek a másikat ( $\mathrm{n}=82)$. A következőkben a 11 általános vélekedést tükröző itemből három indexet alkottunk (2. táblázat). Az összetartozó itemek azonosítása faktoranalízissel történt (Principal Axis Factoring, Direct Oblimin rotáció, $\mathrm{KMO}=0,829$; az egyes faktorok közepes korrelációban állnak egymással: 1 . vs. 2 . faktor $\mathrm{r}=0,466 ; 1$. vs. 3 . faktor $\mathrm{r}=0,567 ; 2$. vs. 3 . faktor $\mathrm{r}=0,591$ ).

2. táblázat

Az itemekböl képzett indexek reliabilitása

\begin{tabular}{|c|c|}
\hline A Facebook felhasználók gyakran függővé válnak. & \multirow{4}{*}{$\begin{array}{l}\text { 1. Facebook használók } \\
\text { negatív megítélése } \\
(\text { Cronbach alfa }=0,771)\end{array}$} \\
\hline $\begin{array}{l}\text { A Facebook felhasználók szeretnének hamis képet mutatni ma- } \\
\text { gukról a külvilágnak. }\end{array}$ & \\
\hline $\begin{array}{l}\text { A Facebook felhasználók nagyképüségükből fakadóan azt hiszik, } \\
\text { hogy mindenkit érdekel életük minden mozzanata. }\end{array}$ & \\
\hline A Facebook felhasználók magamutatogató emberek. & \\
\hline $\begin{array}{l}\text { A Facebook NEM használókat kevésbé manipulálja a média, tuda- } \\
\text { tosabb emberek. }\end{array}$ & \multirow{3}{*}{$\begin{array}{l}\text { 2. A Facebookot nem } \\
\text { használók pozitív meg- } \\
\text { ítélése } \\
(\text { Cronbach alfa }=0,787)\end{array}$} \\
\hline A Facebook NEM használók nem tárnak mindent a világ elé. & \\
\hline $\begin{array}{l}\text { A Facebook NEM használók nem csinálnak valamit csak azért, } \\
\text { mert mindeni más is azt csinálja. }\end{array}$ & \\
\hline A Facebook elveszi az időt a valódi kapcsolatoktól. & \multirow{3}{*}{$\begin{array}{l}\text { 3. A Facebookkal kap- } \\
\text { csolatos negatív attitúd } \\
(\text { Cronbach alfa }=0,773)\end{array}$} \\
\hline A Facebookot veszélyesnek tartom, mert tele van hamis profilokkal. & \\
\hline Akinek van élete, annak nincs szüksége a Facebookra. & \\
\hline
\end{tabular}

\section{1. kutatási kérdés}

Ezek után, az első kutatási kérdésünknek megfelelően a motivációk főbb kategóriáit kívántuk feltárni. A 25 vonatkozó item feltáró faktoranalízise hét faktort azonosított (Principal Axis Factoring, Varimax rotáció, a hét faktor együttesen a variancia 64\%-át magyarázza), melyet a konfirmatív faktoranalízis megerösített $\left(\mathrm{Khi}^{2}(24)=22,06, \mathrm{p}<.001, \mathrm{CFI}=0,918\right.$; TLI=0,94; RMSEA=0,061). A hét faktor a következő: (1) adatbiztonsággal kapcsolatos aggályok, (2) külső 
okok, (3) a közeggel kapcsolatos negatív attitüd, (4) félelem a negatív következményektől, (5) Facebookkal kapcsolatos érdektelenség vs. függőség, (6) társas motiváció hiánya, (7) szociális közeg hatása (3. táblázat).

\section{3. táblázat}

\section{A nem használat motivációinak faktoranalizise}

\begin{tabular}{|c|c|c|}
\hline Faktor & Item & Faktorsúly \\
\hline \multirow{6}{*}{$\begin{array}{l}\text { 1. Faktor } \\
\text { (Cronbach alfa }=0,823)\end{array}$} & $\begin{array}{l}\text { Nem akarok közösségi oldalakon információt } \\
\text { megosztani magamról. }\end{array}$ & 0,847 \\
\hline & $\begin{array}{l}\text { Nem akarok az interneten semmilyen információt } \\
\text { megosztani magamról. }\end{array}$ & 0,826 \\
\hline & Nem szeretem mutogatni magam. & 0,727 \\
\hline & Félek, hogy az adataim nincsenek biztonságban. & 0,716 \\
\hline & Félek, hogy zaklatnának. & 0,58 \\
\hline & $\begin{array}{l}\text { Nem szeretnék állandóan értékelve lenni mások } \\
\text { által. }\end{array}$ & 0,421 \\
\hline \multirow{4}{*}{$\begin{array}{l}\text { 2. Faktor } \\
\text { (Cronbach alfa }=0,704)\end{array}$} & Vallási nézeteimmel nem fér össze. & 0,819 \\
\hline & $\begin{array}{l}\text { Egészségügyi állapotom nem teszi lehetővé, hogy } \\
\text { használjam. }\end{array}$ & 0,818 \\
\hline & Anyagi helyzetem miatt nem tudom használni. & 0,788 \\
\hline & $\begin{array}{l}\text { A munkahelyi szabályok nem engedik meg, hogy } \\
\text { használjam. }\end{array}$ & 0,596 \\
\hline \multirow{4}{*}{$\begin{array}{l}\text { 3. Faktor } \\
\text { (Cronbach alfa }=0,726)\end{array}$} & Nem hiszek a virtuális kapcsolattartásban. & 0,761 \\
\hline & Nem hiszek a virtuális kapcsolatokban. & 0,743 \\
\hline & Időpazarlásnak tartom. & 0,597 \\
\hline & $\begin{array}{l}\text { A szabadidőmet szívesebben töltöm más tevé- } \\
\text { kenységgel. }\end{array}$ & 0,576 \\
\hline \multirow{3}{*}{$\begin{array}{l}\text { 4. Faktor } \\
(\text { Cronbach alfa }=0,71)\end{array}$} & $\begin{array}{l}\text { Ha használnám, az iskolai/munkahelyi teljesítmé- } \\
\text { nyem rovására menne. }\end{array}$ & 0,816 \\
\hline & Túl sok időt venne el más tevékenységektől. & 0,754 \\
\hline & A párkapcsolatom rovására menne. & 0,661 \\
\hline \multirow{3}{*}{$\begin{array}{l}\text { 5. Faktor } \\
(\text { Cronbach alfa }=0,786)\end{array}$} & Nincs rá szükségem. & 0,712 \\
\hline & Félek, hogy függővé válnék. & $-0,599$ \\
\hline & Nem tartom érdekesnek. & 0,576 \\
\hline \multirow{3}{*}{$\begin{array}{l}\text { 6. Faktor } \\
(\text { Cronbach alfa }=0,72)\end{array}$} & Nem érdekel a távolabbi ismerőseim magánélete. & 0,788 \\
\hline & $\begin{array}{l}\text { Nem értem, miért olyan kíváncsiak az emberek } \\
\text { mások életére. }\end{array}$ & 0,722 \\
\hline & $\begin{array}{l}\text { Nem vagyok kíváncsi arra, amit mások meg- } \\
\text { osztanak a Facebookon. }\end{array}$ & 0,566 \\
\hline \multirow{2}{*}{$\begin{array}{l}\text { 7. Faktor } \\
\text { (Cronbach alfa }=0,677)\end{array}$} & A barátaim sem használják. & 0,789 \\
\hline & Nem az én korosztályomnak való. & 0,656 \\
\hline
\end{tabular}


Nemek közötti különbséget csak az 1. faktorban $(\mathrm{p}=0,002)$ találtunk, ahol a nök érték el a magasabb értéket. Aki már regisztrált valaha a Facebookon, szintén magasabb értéket ért el a 4. $(p=0,20)$, az 5. és a 6. faktoron (mindkettő $p<0,05)$. Az idősebbek magasabb értéket mutattak az 1. $(\mathrm{p}<0,001)$, a 4. $(\mathrm{p}<0,01)$ és 7 . faktoron $(0,001)$. A 1 . ábra a hét motivációra adott válaszok átlagát mutatja, vagyis azt, hogy melyek a jellemzőbb, és kevésbé jellemző motivációk (ötfokú skálán).

1. ábra

A nem használat motivációinak elterjedtsége

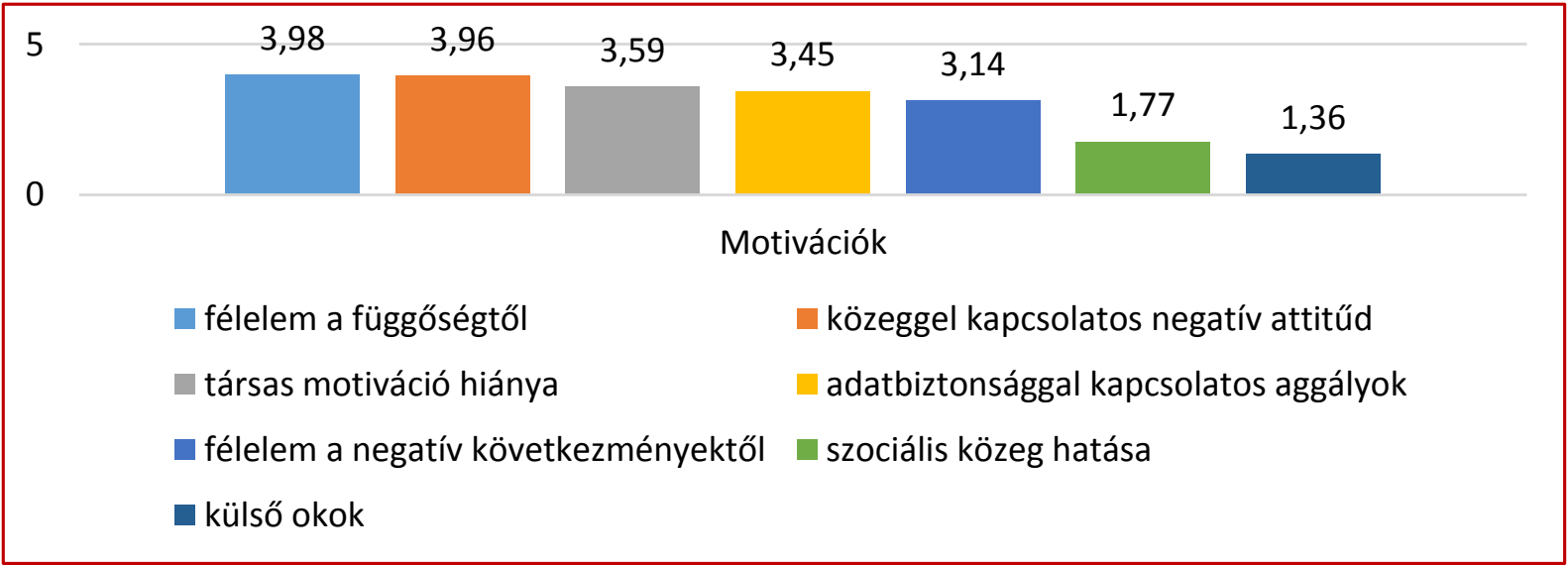

Megvizsgáltuk a kapott motivációk korrelációját a három indexünkkel is, melyek a használókkal, a nem használókkal és a Facebookkal magával kapcsolatos attitüdöket mértek. (4. táblázat)

4. táblázat

A motivációs faktorok és a használókkal, a nem használókkal, valamint a Facebookkal szembeni attitüd korrelációi

\begin{tabular}{|l|c|c|c|c|c|c|c|}
\hline & $\begin{array}{c}1 . \\
\text { faktor }\end{array}$ & $\begin{array}{c}2 . \\
\text { faktor }\end{array}$ & $\begin{array}{c}3 . \\
\text { faktor }\end{array}$ & $\begin{array}{c}4 . \\
\text { faktor }\end{array}$ & $\begin{array}{c}5 . \\
\text { faktor }\end{array}$ & $\begin{array}{c}6 . \\
\text { faktor }\end{array}$ & $\begin{array}{c}7 . \\
\text { faktor }\end{array}$ \\
\hline $\begin{array}{l}\text { Használókkal kapcsolatos } \\
\text { negatív attitüd }\end{array}$ & $\begin{array}{c}0,275^{*} \\
*\end{array}$ & - & $0,170^{*}$ & $\begin{array}{c}0,213^{*} \\
*\end{array}$ & - & - & - \\
\hline $\begin{array}{l}\text { Nem használókkal kap- } \\
\text { csolatos pozitív attitüd }\end{array}$ & $\begin{array}{c}0,258^{*} \\
*\end{array}$ & - & $\begin{array}{c}0,294^{*} \\
*\end{array}$ & - & - & - & - \\
\hline $\begin{array}{l}\text { Facebookkal kapcsolatos } \\
\text { negatív attitüd }\end{array}$ & $\begin{array}{c}0,277^{*} \\
*\end{array}$ & $0,179^{*}$ & $\begin{array}{c}0,390^{*} \\
*\end{array}$ & $\begin{array}{c}0,316^{*} \\
*\end{array}$ & - & - & - \\
\hline
\end{tabular}




\section{5. táblázat}

Ha regisztrált már valaha a Facebookra, miért hagyta abba a használatát?

\begin{tabular}{|c|c|c|}
\hline Kategória & $\begin{array}{c}\text { fó } \\
n=39\end{array}$ & Említés \\
\hline Én- és adatvédelem & 13 & $\begin{array}{l}\text { „Meg akartam védeni a szociális hálómat.” } \\
\text { „Úgy éreztem, hogy szükségem van arra, hogy kicsit "egyedül } \\
\text { legyek", és ne legyek elérheto”, csak azok számára, akik igazán } \\
\text { közel állnak hozzám.” } \\
\text { „Nem találtam semmi jót abban, hogy akármikor elérheto” } \\
\text { vagyok olyanoknak, akik offline egy szóra sem méltatnak.” } \\
\text { „...hátrányos, hogy a személyes, csak kevesekre tartozó dolgok } \\
\text { is sokkal többek számára válik elérhetővé.” } \\
\text { „Túl sok személyes információt lehet rajta megtudni a má- } \\
\text { sikról...” }\end{array}$ \\
\hline $\begin{array}{l}\text { Felülettel szembeni } \\
\text { ellenérzések }\end{array}$ & 12 & $\begin{array}{l}\text { „Nehezen volt átlátható, használható számomra, interneten } \\
\text { olvastam, hogy nehezen lehet törölni, és kaptam felesleges e- } \\
\text { maileket, ezért inkább biztos, ami biztos, töröltettem magam.” } \\
\text { „Idegesített a sok ostoba poszt és lájk. A kapcsolattartást e-mail- } \\
\text { en és skypon is meg tudtam oldani, így feleslegessé váltt.” } \\
\text { „Sajnos rengeteg olyan információ jutott el hozzám a Face- } \\
\text { bookon keresztül, amit szerettem volna figyelmen kívül hagyni.” }\end{array}$ \\
\hline Időtényezö & 11 & $\begin{array}{l}\text { „Túl sok időt, töltötttem el rajta, és nem bírtam megállni hogy ne } \\
\text { 'faszbúkozzak'. Mivel számítógép elötti munkát végzek/végez- } \\
\text { tem, és akkortájt olyan helyen dolgoztam, ahol az internetes } \\
\text { oldalak látogatása nem volt korlátozva...” } \\
\text { „Eleve csak úgy mentem fel, hogy kipróbálom, aztán szöve- } \\
\text { vényesebbnek bizonyult, mint hittem és kiléptem, mert a masz- } \\
\text { szívsága miatt láttam, hogy több időt kéne majd ráfordítanom, } \\
\text { mint szeretnék.” } \\
\text { „Rengeteg időt vett el. Mások profilját már nem nagyon néze- } \\
\text { gettem, de ha csak az üzenetek megválaszolására rászántam az } \\
\text { időt, már az is fél-1 órát elvett a napomból.” }\end{array}$ \\
\hline $\begin{array}{l}\text { Személyes kapcsolat- } \\
\text { tartás preferálása }\end{array}$ & 8 & $\begin{array}{l}\text { „Hogy ne kifelé, hanem befelé éljek, kapcsolataimat intimi- } \\
\text { tásban éljem meg, (...) ne nézegessem a régi szerelmeimet és } \\
\text { párkapcsolataikat.” } \\
\text { „... a legtöbb 'ismerősöm' nem volt az ismerősöm. Ha valaki } \\
\text { szeretne tőlem valamit, vagy én szeretnek valakitől valamit, } \\
\text { felhívom és/vagy találkozom vele.” } \\
\text { „...egy idő után úgy éreztem, hogy elveszik a személyes talál- } \\
\text { kozások varázsa, mivel mindent tudunk egymásról a Facebook- } \\
\text { nak köszönhetően.” }\end{array}$ \\
\hline Konfliktusforrás & 3 & $\begin{array}{l}\text { „Zavart, hogy látják, ha elolvasok egy üzenetet. Volt abból kelle- } \\
\text { metlen helyzet, hogy elolvastam, de nem válaszoltam. Megelé- } \\
\text { geltem ezeket a problémákat és drasztikus megoldást válasz- } \\
\text { tottam. Így kevésbe vagyok elérhetö, de ezt még élvezem is. :)” }\end{array}$ \\
\hline Mások élete & 3 & $\begin{array}{l}\text { „Nem vonz a mások életének monitorozása, és valótlan színben } \\
\text { való feltüntetése, ebből fakadó téves következ-tetések alkotása.” }\end{array}$ \\
\hline Külső ok & 1 & $\begin{array}{l}\text { „A szüleim ellenezték, nem tudtak róla és nem akartam a hátuk } \\
\text { mögött csinálni.” }\end{array}$ \\
\hline
\end{tabular}




\section{2. kutatási kérdés}

A kérdőíves kikérdezés során nyílt végü kérdéseket alkalmaztunk az alábbi kérdések megválaszolására: (1) akik már regisztráltak valaha a Facebookra, miért hagyták abba annak használatát; (2) volt-e valamilyen konkrét negatív élményük a felületen; (3) származott-e valamilyen hátrányuk abból, hogy nem volt Facebook fiókjuk; valamint (4) az általuk használt felületeket miért preferálják a Facebookkal szemben. A Facebook használók kérdőívében szereplö nyílt kérdések segítségével pedig arról gyüjtöttünk információt, hogy (1) a felhasználónak volt-e valamilyen konkrét negatív élménye a Facebookon és (2) hogy ha szüneteltette már a Facebook profilját, miért tette azt. A kérdések megválaszolását nem tettük kötelezővé.

A nem használóktól arra a kérdésre, hogy miért hagyták abba a Facebook használatát, 38 válasz érkezett. Leggyakoribb távozást előidéző tényező az én- és adatvédelemmel kapcsolatos aggályok (13), majd a közeggel szembeni ellenérzések következtek, úgy mint unalmas, felesleges, kéretlen vagy ostoba információk, átláthatatlan felület (12 fö). A harmadik leggyakoribb említést az időfaktor kapta (11 fö), melyet a személyes kapcsolattartás preferálása ( 8 fö), a felület konfliktusforrásként való azonosítása (3 fö), a mások életébe való betekintés (3 fó), végül a külső ok és a függőséggel való szembesülés egy-egy említése követte (5. táblázat).

Azzal kapcsolatban, hogy a nem használók távozása mögött állt-e valamilyen negatív élmény vagy tapasztalat, csak 12 értékelhető válasz állt rendelkezésünkre, melyek gyakoriság szerinti sorrendje: a túlzott elérhetőség problémája (4 fö), valamilyen konfliktus említése ( 3 fö), valamint - 1-1 említéssel - a zaklatás, a negatív érzelmi reakció, a frusztráció, a túlzott információ, a felületre jellemző személytelenség, valamint negatív vélemény a Facebook felhasználókról.

A következőkben arra voltunk kíváncsiak, hogy milyen típusú hátrányt okozott a nem használók számára a Facebook felületétől való távolmaradás. Többségük (114fö; 68,7\%), véleménye szerint semmilyen veszteséget nem eredményezett a Facebook profiljuk hiánya. Azok válaszaiból, akik beszámoltak valamilyen hátrányról, két hangsúlyos terület rajzolódott ki: az információs aszimmetria vagy hátrány és a kapcsolattartás során felmerülö nehézség. További egy-egy említést kapott az integrált felületek elterjedésével bizonyos alkalmazásoknál a Facebook profil elönyös volta, a szervezési nehézség kiemelése, valamint a diákok online tevékenységének megismerésének előnyei (6. táblázat).

6. táblázat

Származott abból valaha hátránya, hogy nem volt Facebook profilja?

\begin{tabular}{|c|c|c|}
\hline Kategória & $\begin{array}{c}\text { fö } \\
(n=52)\end{array}$ & Említés \\
\hline $\begin{array}{l}\text { Információs asszi- } \\
\text { metria/hátrány }\end{array}$ & 39 & $\begin{array}{l}\text { „... pl. most az egyetemi csoportunk is a Facebookon van, így nehe- } \\
\text { zebben jutnak el hozzam az informáciok, illetve ha valaki 'eventet' } \\
\text { szervez, akkor is mindent oda posztolnak és hozzám minden info } \\
\text { késve jut el." }\end{array}$ \\
\hline $\begin{array}{l}\text { Kapcsolattartás } \\
\text { nehezítettsége }\end{array}$ & 10 & $\begin{array}{l}\text { „Nem tudtam felvenni a kapcsolatot bizonyos emberekkel.” } \\
\text { „Könnyebb lenne néha tartani a kapcsolatot ismerösökkel, meg tudni, } \\
\text { hogy mi van velük.” }\end{array}$ \\
\hline Szervezési nehézség & 6 & „Facebookon könnyebb lett volna pl. osztálytalálkozót is szervezni.” \\
\hline Integrált felületek & 1 & „Néhány alkalmazásnál belefutottam, hogy jó lett volna, ha lett volna.” \\
\hline $\begin{array}{l}\text { Diákok online akti- } \\
\text { vitása }\end{array}$ & 1 & $\begin{array}{l}\text { „Időnként az az érzésem, hogy a tanítás szempontjából lenne előnye } \\
\text { annak, ha a tanítványaim Facebookos aktivitását, témáit látnám.” }\end{array}$ \\
\hline
\end{tabular}


A Facebook használók felülethez füződő negatív élményeikkel kapcsolatos válaszaiban a leggyakoribb az én- és adatvédelemmel kapcsolatos tapasztalat említése (15). Itt megtalálható az ismeretlenektől érkező üzenetek letiltásának lehetetlensége, valamint a nemkívánatos tartalom (fénykép) törlésének sikertelensége. Az én- és adatvédelmi hiányosság említését követi a zaklatásra (9), a nem kívánatos tartalomra (5), valamint a párkapcsolatot érintő élményre (1) való utalás (7. táblázat).

\section{7. táblázat}

Volt valamilyen konkrét negatív élménye a Facebookon?

\begin{tabular}{|c|c|c|}
\hline Kategória & fó & Említés \\
\hline $\begin{array}{l}\text { Én- és adatvé- } \\
\text { delem }\end{array}$ & 15 & $\begin{array}{l}\text { „Még az elején felraktam a telefonszámomat, ha valakinek sürgősen kéne } \\
\text { (akkor még nem az okos telefonok korszakát éltük). Párszor jól is jött, } \\
\text { aztán egy ismerösöm a megkérdezésem nélkül kiadta 3. személynek vala- } \\
\text { mi nagyon gyanús munkával kapcsolatban. Azóta nincs fent a számom } \\
\text { (mai fejjel nem is tudom, hogy gondoltam).” } \\
\text { „Nehéz letiltani valakit, mert üzenetek így is, úgy is jönnek tőle.” „Nem } \\
\text { tudtam leszedetni egy rólam készült fotót.” }\end{array}$ \\
\hline Zaklatás & 9 & $\begin{array}{l}\text { „A profilomat duplikálták, és sátánista elemekkel torzítva jelölgették be } \\
\text { az összes ismerösömet.” „Durva, trágár kommenteket kaptam egy bizo- } \\
\text { nyos személytől minden képemhez.” "Valaki a nevemmel regisztrált a } \\
\text { Facebookon és keltette rossz híremet.” }\end{array}$ \\
\hline $\begin{array}{l}\text { Nem kívánatos } \\
\text { tartalom }\end{array}$ & 5 & $\begin{array}{l}\text { „Nem szeretem az olyan embereket, akik úgy érzik a véleményüket min- } \\
\text { denféleképpen mindenröl meg kell osztaniuk, mikor senki sem kérdezte } \\
\text { őket.” } \\
\text { „Vannak emberek, akik sok hülyeséget tesznek ki a falukra, de azokat is } \\
\text { blokkolom egy idő után.” }\end{array}$ \\
\hline Párkapcsolati & 1 & $\begin{array}{l}\text { „Olyan információkhoz jutottam, amit jobb lett volna nem tudni (párkap- } \\
\text { csolati vonatkozású, hütlenség derült ki).” } \\
\text { „Amit az ismerőseimen láttam, az, hogy párkapcsolatokba bele tud } \\
\text { zavarni. Pl hogy kiírja, hogy a másik fél látta az üzenetet, de még nem } \\
\text { válaszolt. Ilyenkor az embert zavarja, hogy még miért nem. Valamint az } \\
\text { emberek csekkolják, hogy ki lett a párjának ismerőse, mit like-olt, ami } \\
\text { felesleges konfliktusokhoz tud vezetni.” }\end{array}$ \\
\hline
\end{tabular}

Azon felhasználók, akik már legalább egyszer deaktiválták vagy törölték profiljukat, az okok között a következőket említették: én- és adatvédelemmel kapcsolatos, különösen az ismeretlen ,ismerősök” (3); kapcsolati probléma, úgymint Facebook féltékenység, szakítás és az offline kapcsolatoktól való eltávolodás (3); a felület felesleges, unalmas volta (3); a túlzott időráfordítás (2); a tartalom feletti kontroll elvesztésének érzése (2), a nyugalom igénye, fogadás miatti és a zaklatás (1) (8.táblázat). 
8. táblázat

Ha szüneteltette meg már a Facebook profilját, miért tette?

\begin{tabular}{|l|c|l|}
\hline \multicolumn{1}{|c|}{ Kategória } & fo & \multicolumn{1}{c|}{ Említés } \\
\hline Én- és adatvédelem & 3 & $\begin{array}{l}\text { „Túl sok olyan ismerősöm volt, akikkel nem tartottam a kap- } \\
\text { csolatot, és nem is akartam.” } \\
\text { „Túl nött a funkcióján, sok ismeretlen ismerösöm lett! Jó dön- } \\
\text { tés volt, tudatosabban állok a FB-hoz.” }\end{array}$ \\
\hline Kapcsolati probléma & 3 & $\begin{array}{l}\text { „Párkapcsolati féltékenységnek engedve.” } \\
\text { „Egy barátságom az ellentettjére fordult, és így csökkentettem } \\
\text { az adott személlyel való érintkezés mennyiségét.” }\end{array}$ \\
\hline Felülettel kapcsolatos & 3 & $\begin{array}{l}\text { „Mert nem éreztem, hogy bármiért fontos lenne a profilomnak } \\
\text { megmaradnia.” }\end{array}$ \\
\hline Időfaktor & 2 & $\begin{array}{l}\text { „Nem tudtam hosszú ideig foglalkozni vele, válaszolni üzene- } \\
\text { tekre, posztokra.” }\end{array}$ \\
\hline $\begin{array}{l}\text { Kontroll elvesztésének } \\
\text { érzése }\end{array}$ & 2 & $\begin{array}{l}\text { „Úgy találtam, túl sok kompromittáló posztom volt, és sok ide- } \\
\text { gesítő ismerösöm, ezért úgy éreztem, kicsit elveszítettem a } \\
\text { kontrollt a profilom felett.” } \\
\text { „Nehezen tudtam már követni és kezelni az oldalt.” }\end{array}$ \\
\hline
\end{tabular}

Fontosnak tartottuk foglalkozni azzal a kérdéssel is, hogy a Facebookot nem használók milyen egyéb közösségi média felületet használnak és milyen okból. Az előbbi kérdésre adott válaszokat a 2. ábra foglalja össze. Jól látható, hogy elsősorban specializált felületeket használnak, illetve 39\%-uk saját bevallás alapján nem használ semmit. Az okok között elsősorban az adatvédelmi problémák kerültek elő, más rendszereket zártabbnak vagy biztonságosabbnak gondoltak. Többen hivatkoztak időhatékonyságra, szakmai szempontokra, megszokásra, illetve az egyirányú kommunikáció preferálására. Kiemelték továbbá a másik platform előnyeit, mint például a gyorsabb, egyszerübb használatot, az érdekesebb tartalmakat, illetve azt, hogy máshol nem kell regisztrálni, nincs elköteleződés.

2. ábra

Egyéb közösségi média felület használata

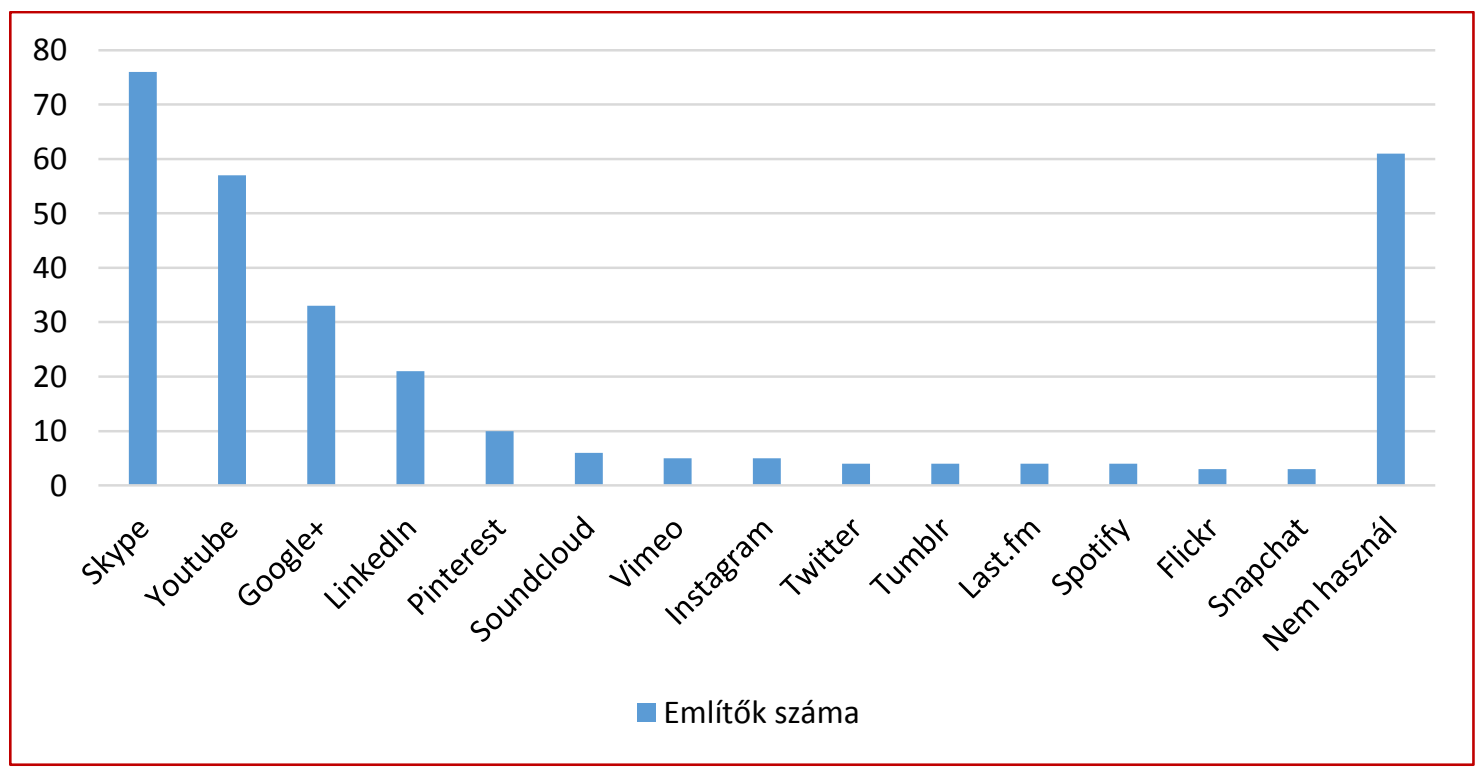




\section{3. kutatási kérdés}

A harmadik kutatási kérdés mindkét csoportnál a saját és a másik csoporttal kapcsolatos sztereotípiák feltárására irányult.

A 3. ábrán jól látható, hogy a nem használók meglehetősen nagy különbségeket látnak a Facebookot használók és a nem használók között: a lázadó-konform és a barátságos-barátságtalan tulajdonságpáron kívül mindenütt máshol szignifikánsak a különbségek $(p<0,05)$. A nem használók szerint a nem használók idősebbek, több közöttük a férfi, introvertáltabbak, visszahúzódóbbak, konzervatívabbak, ugyanakkor intelligensebbek, érzelmileg stabilabbak, felelősségteljesebbek és feladatorientáltabbak. A felhasználók jellemzése épp ezzel ellentétes: fiatal, extrovertált, exhibicionista emberek, kevésbé jellemző rájuk a kötelességtudat vagy az intelligencia, és jellemzően nők. További jellegzetességük, hogy sokkal átlagosabbak, mint a nem használók. E jellemzésekben találtunk nemi és életkorhoz köthető különbségeket. A nők a használókat extrovertáltabbnak, nyíltabbnak, exhibicionistábbnak, társaságkedvelöbbnek, viszont átlagosabbnak látják, mint a férfiak $(\mathrm{df}=164 ; \mathrm{p}<0,05)$. Az idősebbek szorgalmasabbnak, eredetibbnek, magasabb önbecsülésünek, lázadóbbnak és kevésbé kötelességtudónak látják a használókat $(\mathrm{df}=164 ; \mathrm{p}<0,05)$. A saját csoport jellemzésében nemi különbséget nem találtunk, a kor viszont újfent fontos szerepet játszott. Az idősebbek kockázatkerülőbbnek, lustábbnak, átlagosabbnak, alacsonyabb önbecsülésűnek, konformabbnak, kevésbé magabiztosnak, barátságtalanabbnak, érzelmileg instabilabbnak, kevésbé intelligensnek és motiválatlanabbnak látják a nem használókat $(\mathrm{df}=164 ; \mathrm{p}<0,05)$. A Facebookot elhagyók és a soha nem regisztráltak között nem találtunk különbségeket.

\section{3. ábra}

A nem használók attitüdjei

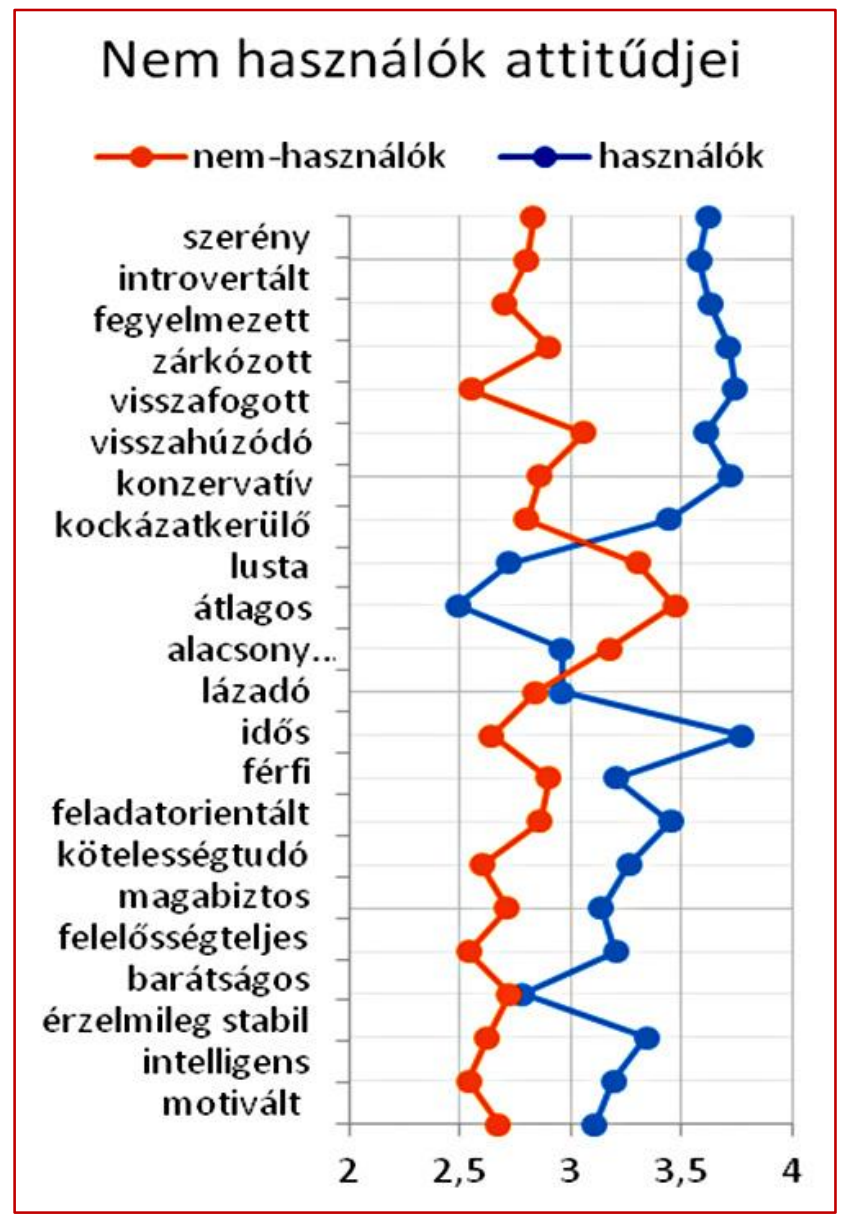


A Facebook használók kísértetiesen hasonló képet festettek mind a saját, mind a nem használók csoportjáról, mint a nem használók (4. ábra). Hozzájuk képest eltérést csak néhány tulajdonság esetében találtunk: a nem használókat konzervatívabbnak, átlagosabbnak, és idősebbnek, míg saját csoportjukat fiatalabbnak és barátságosabbnak tartják, mint a nem használók $(\mathrm{p}<0,05)$. A saját csoport megítélésekor két tulajdonság mentén volt nemi különbség: lustaszorgalmas és motivált-motiválatlan $(\mathrm{p}<0,05$; a férfiak megítélése volt negatívabb mindkét esetben). A nem használók megítélésében nem volt nemi különbség. Életkori különbségeket csak a nem használók megítélésében találtunk, a fiatalok a nárcisztikusabbnak, exhibicionistábbnak, lustábbnak, átlagosabbnak és konformabbnak látták őket $(\mathrm{p}<0,05)$.

4. ábra

A Facebook használók attitüdjei

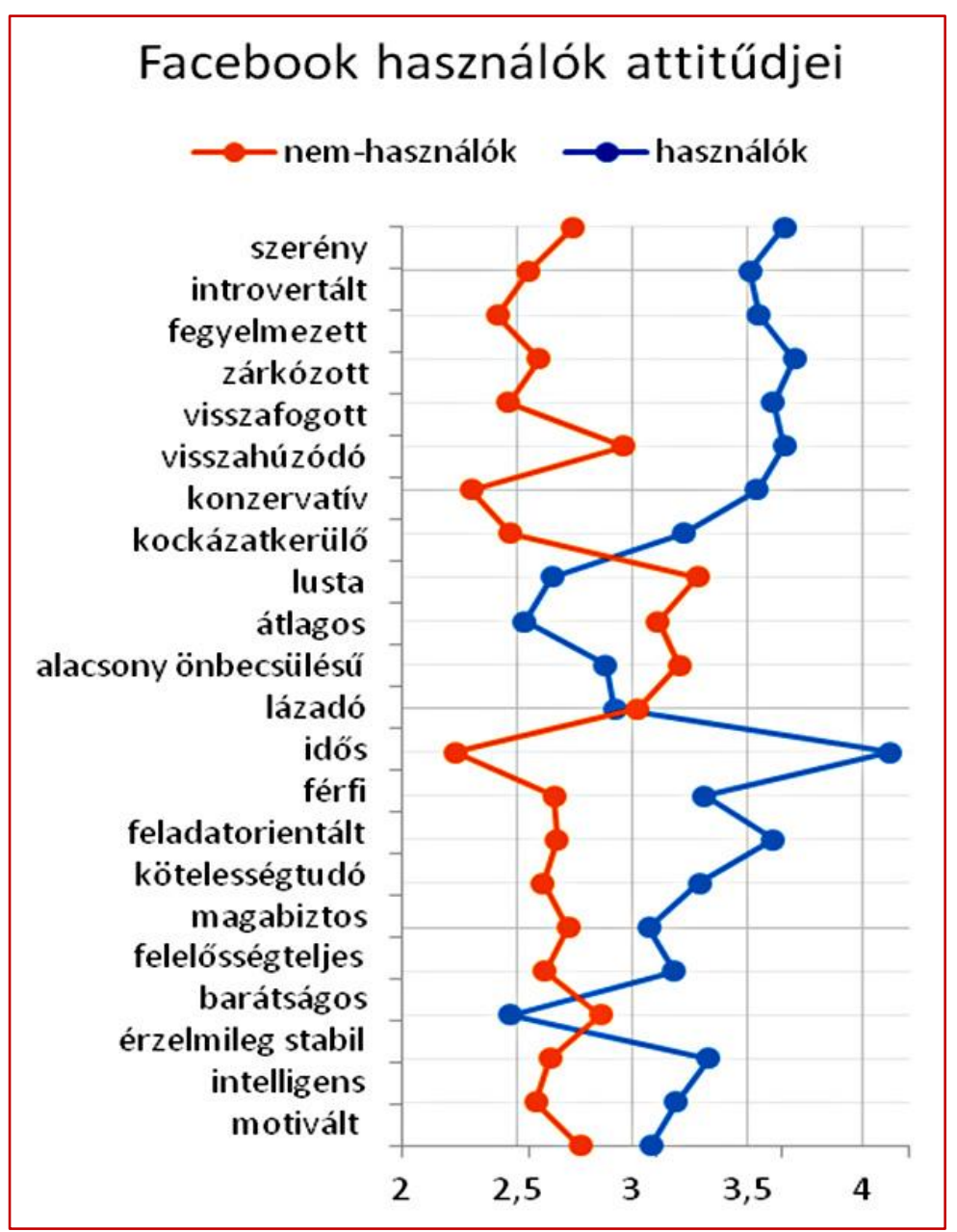

\section{Kutatási kérdés}

A faktoranalízis eredményeképp kapott hét faktor alapján az adatokon elöször hierarchikus klaszterelemzést futtattunk le, meghatározva az optimális klaszterszámot, majd megerősítés céljából „k-mean” klaszteranalízist (minimal link analysis) is végeztünk 3 és 6 közötti klaszterszámot megjelölve, melyek közül többszöri lefuttatás után a négyklaszteres bizonyult a legstabilabbnak. Az első klaszterbe tartozókra $(\mathrm{n}=42)$ az adatvédelemmel kapcsolatos aggályok (1), a negatív következményektől való félelem (4) és a nem érdekes (5) faktoron elért 
alacsony érték volt jellemző. A következő klaszter tagjai $(n=36)$ kiugróan alacsony értéket értek el minden faktoron, kivéve külső okok (2), társas okok (7) és adatvédelmi aggályok (1). A legnépesebb klaszterbe tartozók $(n=67)$ a többieknél magasabb értéket értek el az adatvédelmi aggályok (1), a közeggel való ellenállás faktoron (3), illetve a nem érdekes és nem érdekel faktorokon $(5,6)$ és közepeset a negatív következmények faktoron (4). Az utolsó klaszterbe $(n=21)$ tartozók elsődleges indítéka a külső kényszer (2). Annak érdekében, hogy feltárjuk a kapott klaszterek közötti különbségeket az egyéb változók mentén, khí-négyzet próbákat és variancia-analíziseket is végeztünk. Nemi különbséget az első és a harmadik klaszter esetében találtunk ( $k$ hí2 $=8,128 ; \mathrm{df}=3 ; \mathrm{p}<0,05$ ), a nők aránya az első klaszterben volt magasabb, a férfiaké pedig a harmadikban. Korhoz köthető különbségek is akadtak, az első és a harmadik klaszterbe tartozók voltak a fiatalabbak $(\mathrm{F}=6,202 ; \mathrm{df}=162 ; \mathrm{p}<0,01)$. Megvizsgáltuk, hogy a három képzett indexben elért eredmények mutatnak-e különbségeket a különböző klasztereknél. A Facebookot használók negatív megítélése legalacsonyabb értéket a második klaszternél mutatott, legmagasabbat pedig a harmadiknál $(\mathrm{F}=3,499 ; \mathrm{df}=162 ; \mathrm{p}=0,02$; post hoc Tukey). A nem használók megítélésében nem voltak különbségek. A Facebookkal szemben leginkább negatív elöítéletekkel a harmadik klaszter tagjai élnek $(F=1,005 ; \mathrm{df}=162 ; \mathrm{p}=0,015$ post hoc Tukey).

\section{Diszkusszió}

Az egyik legfontosabb eredményünk az, hogy láthatóvá tettük a spontán felidézett indokok és a zárt kérdésekre adott válaszok közti különbségeket. Míg a nyitott kérdésekben a nem használók inkább praktikus magyarázatokat adtak a nem használatra, a zárt kérdésekre adott válaszok azt mutatják, hogy a szimbolikus (vagyis mélyebben gyökerező, lélektanibb jellegü) okok is éppoly fontos szerepet játszanak a döntésükben. Ilyen szimbolikus okok lehetnek például a különböző félelmek (addikciótól, a negatív következményektől, a magánjellegű adatok kiadásától) vagy a közeggel kapcsolatos negatív attitüdök. Portwood-Stacer (2012) arra is rámutat, hogy a praktikus és szimbolikus okok gyakran keverednek: amikor például időpocsékolásként tekint valaki a Facebook használatra, akkor indirekten úgy mutatja be önmagát, mint akinek fontos a hatékonyság.

A nyitott kérdésekből kiderült, hogy a nem használók többsége számára nem okoz semmilyen veszteséget a Facebooktól való távolmaradás. Akik viszont beszámoltak valamilyen hátrányról, azok az információhoz jutás nehézségéről, abból való kimaradásról (információs aszimmetria), valamint az ismerősökkel való kapcsolattartás nehezítettségéröl számoltak be. A használók felülethez füződő negatív élményeikkel kapcsolatos válaszaiban leggyakoribb az én- és adatvédelemmel kapcsolatos tapasztalat említése, ezen belül a leggyakoribb említést a zaklatás érte el.

Az általunk kapott motivációs faktorok jórészt rímelnek a szakirodalomban kapottakra, például Dindar és Akbulut (2014) négyes felosztására, akik külső okokat (external factors), praktikusakat (mechanics), az észlelt hasznosságra (perceived usefulness), valamint az én elrejtésére vonatkozókat (self-concealing) említettek. A megvizsgált csoportok mentén mutatkozott némi eltérés a motivációkban. A nők magasabb értéket adtak az adatbiztonsággal kapcsolatos aggályokra, a már regisztráltakat elsősorban a félelmek tartották vissza (a negatív következményektől és a függőségtől), illetve a társas motiváció hiánya. Az idősebbeket leginkább az adatbiztonsággal kapcsolatos aggályok, a negatív következményektől való félelmek motiválták, valamint az, hogy úgy érezték, hogy a Facebook nem az ő korosztályuknak való. A korábban regisztráltak és nem regisztráltak között nem találtunk különbségeket.

Az egyik általunk fontosnak gondolt, de a szakirodalomban eddig jórészt mellözött szimbolikus okot, a használókkal kapcsolatos sztereotípiákat kiemelten is vizsgáltuk. Söt, hogy teljesebb legyen a kép, a használókat is megkérdeztük önmagukkal és a nem haszná- 
lókkal kapcsolatos sztereotípiáikról. Ebböl az rajzolódott ki, hogy a használók és a nem használók képe elég konszenzuális a társadalomban, nem volt jelentékeny különbség a két csoport reprezentációi között. Jellemzö továbbá, hogy a két csoport képe egymáshoz viszonyítva egymás ellentétpárjaként létezik, szinte tükörképként. Az, hogy mindkét csoport nagy különbséget lát a két csoport között, arra utal, hogy a tényező társadalmilag fontos, jelentőségteljes. A szakirodalomban megfogalmazott azon félelem, hogy a nem használatot mint deviáns, stigmatizált szerepként percipiálnák (Baumer et al. 2013), egyáltalán nem igazolódott be. Leginkább azt tapasztaltuk, hogy a nem használókról kialakított kép éppoly ambivalens - vagyis tartalmaz negatív és pozitív elemeket egyaránt - mint a használók reprezentációja. A nem használókat szinte konszenzuálisan mindenki a szociális tulajdonságok mentén visszahúzódóbbnak látja, ugyanakkor a teljesítményhez kapcsolódókban kiemelkedőnek. Közvélekedésben tehát egyszerre van jelen a használat irányába történő nyomás és a nem használók iránti megbecsülés.

A motivációk alapján azonosítottuk a nem használókon belüli klaszterek profiljait. A legkevesebben abba a csoportba tartoznak, amely külső okok miatt nem használja a platformot; ők jellemzően idősebbek, egyenlő arányban nők és férfiak. A következő klaszter tagjai rendelkeznek a legkevésbé negatív attitüddel a használókról, illetve a Facebookkal szembeni ellenállás sem jellemezte öket különösebben, távolmaradásukat részben az adatbiztonsággal kapcsolatos aggályaik, illetve az magyarázza, hogy úgy érzik, kortársaik, ismerőseik nem használják az oldalt. E csoport tagjai jellemzően az idősebbek közül kerülnek ki. A harmadik csoport tagjait leginkább úgy írhatjuk le, mint akiket a félelmeik tartanak vissza, félelem az addikciótól, a negatív következményektől, illetve attól, hogy mi történik az adataikkal. Jellemzi őket, hogy negatívan ítélik meg a használókat, és főleg nők. A legnépesebb klasztert azok alkotják, akiket elsősorban a Facebookkal és az azt használókkal szembeni elutasító attitüddel jellemezhetnénk, ez hozzáállás alapozza meg a nem használat legfőbb motivációját. Több férfi tartozik ide, mint nő, és ez volt a legalacsonyabb átlagéletkorral leírható csoport.

Összegzésül elmondható, hogy kutatásunk elérte kitüzött céljait, ez azonban csak az első lépés a Facebookot nem használók motivációinak megértéséhez. Az eredmények alapján fontos újragondolni, illetve módosítani a használt mérőeszközöket, továbbá nagyobb mintaelemszámot kell elérni, amit részben a kérdöív más nyelvekre történő lefordításával, így más országok nem használóit elérve szeretnénk megtenni. Hozzá kell tenni továbbá, hogy a tudatosabb vagy erösebb ellenérzésekkel élök talán szívesebben válaszoltak, hiszen a válaszadáshoz szükség volt némi önreflexióra, továbbá a magasabban kvalifikáltak jelenléte talán elötérbe tolt bizonyos motivációkat (pl. a produktivitást). A reprezentativitás talán sérült (bár arra nem is törekedtünk), de a jelenség mélységeit jobban meg tudtuk érteni.

Legfőbb tanulság, hogy a Facebook nem használatának vizsgálatakor fontos szempont, hogy a jelenséget szükebb és tágabb szociális kontextusban szemléljük, a használat és nem használat megértéséhez a gazdasági, pszichológiai tényezők mellett az egyén mindennapjainak dinamikáját is figyelembe kell venni, többek között a technológia és a mindennapi élet illeszkedését. (Selwyn 2003) 


\section{Irodalom}

Baker, Rosland K. - White, Katherine M. (2011) In their own words: Why teenagers don't use social networking sites. CyberPsychology, Behavior and Social Networking: the impact of the Internet, multimedia and virtual reality on behavior and society. 2011/14. 6. 395398. http://dx.doi.org/10.1089/cyber.2010.0016

Baumer, Eric. P. S. - Adams, Phil - Khovanskaya, Vera D. - Liao, Tony C. - Smith, Madeline E. - Sosik, Victoria Schwanda - Williams, Kaiton (2013) Limiting, Leaving, and (re)Lapsing: An Exploration of Websites by University Students. Scientific Journal of Media Education, 2013/41. 137-145. http://dx.doi.org/10.1145/2470654.2466446

Caers, Ralf - Feyter, Tim De - Couck, Marijke De - Stough, Talia - Vigna, Claudia - Du Bois, Cind (2013) Facebook literature review. New Media \& Society. 2013/15. 6. 9821002. http://dx.doi.org/10.1177/1461444813488061

Dindar, Muhterem - Akbulut, Yavuz (2014) Why do pre-service teachers quit Facebook? An investigation on 'quitters forever' and 'quitters for a while'. Computers in Human Behavior, 2014/39. 170-176. http://dx.doi.org/10.1016/j.chb.2014.07.007

Hargittai Eszter (2008) Whose space? Differences Among Users and Non-Users of Social Network Sites. Journal of Computer-Mediated Communication, 2008/13. 276-297. http://dx.doi.org/10.1111/j.1083-6101.2007.00396.x

Lampe, Cliff - Vitak, Jessica - Ellison, Nicole (2013) Users and Nonusers: Interactions between Levels of Facebook Adoption and Social Capital

URL: $\quad$ https://vitak.files.wordpress.com/2009/02/lampe_vitak_ellison-2013-cscw.pdf Utolsó letöltés időpontja: 2015. augusztus 24.

http://dx.doi.org/10.1145/2441776.2441867

Ljepava, Nikolina - Orr, Robert R. - Locke, Sean és Ross, Craig (2013) Personality and Social Characteristics of Facebook Non-Users and Frequent Users. Computers in Human Behavior, 2013/29. 1602-1607. http://dx.doi.org/10.1016/j.chb.2013.01.026

Portwood-Stacer, Laura (2012) Media refusal and conspicuous non-consumption: The performative and political dimensions of Facebook abstention. New Media \& Society online version. URL: http://lauraportwoodstacer.com/wp-content/uploads/2013/03/ mediarefusalandconspicuousnonconsumption.pdf Utolsó letöltés időpontja: 2015. augusztus 24. http://dx.doi.org/10.1177/1461444812465139

Rainie, Lee - Smith, Aaron - Duggan, Maeve (2013) Coming and going on Facebook. Pew Internet Report URL: www.pewinternet.org/files/old-media//Files/Reports/2013/PIP Coming_and_going_on_facebook.pdf Utolsó letöltés időpontja: 2015. augusztus 24.

Ryan, Tracii - Xenos, Sophia (2011) Who uses Facebook? An investigation into the relationship between the Big Five, shyness, narcissism, loneliness, and Facebook usage. Computers in Human Behavior, 2011/27. 1658-1664. http://dx.doi.org/10.1016/j.chb.2011.02.004

Sheldon, Pavica (2012) Profiling the non-users: Examination of life-position indicators, sensation seeking, shyness, and loneliness among users and non-users of social network sites. Computers in Human Behavior, 2012/28. 1960-1965.

http://dx.doi.org/10.1016/j.chb.2012.05.016

Selwyn, Neil (2003) Apart from technology: understanding people's non-use of information and communication technologies in everyday life. Technology in Society, 2003/25. 99-116. http://dx.doi.org/10.1016/S0160-791X(02)00062-3 
Socialdaily (2015) URL: http://analytics.socialdaily.com/hu/facebook/countries/hu/ Utolsó letöltés időpontja: 2015. augusztus 24.

Stieger, Stefan - Burger, Christoph - Bohn, Manuel - Voracek, Martin (2013) Who commits virtual identity suicide? Differences in privacy concerns, Internet Addiction, and personallity between Facebook users and quitters. Cyberpsychology, Behavior, and Social Networking, 2013/16, 9. 629-634. http://dx.doi.org/10.1089/cyber.2012.0323

Tufekci, Zeynep (2008) Grooming, Gossip, Facebook and MySpace. Information, Communication \& Society, 2008/11, 4, 544-564. http://dx.doi.org/10.1080/13691180801999050

Turan, Zeynep - Tinmaz, Hasan - Goktas, Yuksel (2013) The Reasons for Non-Use of Social Networking. Comunicar, 2013/21. 137-145. http://dx.doi.org/10.3916/C41-2013-13

Ujhelyi Adrienn (2014) A Facebook szociálpszichológiája. Szakirodalmi összefoglaló. Alkalmazott Pszichológia, 2014/1. 113-132.

Wilson, Robert E. - Gosling, Samuel D. - Graham, Lindsay, T. (2012) A Review of Facebook Research in the Social Sciences. Perspectives on Psychological Science, 2012/7. 3. 203-220. http://dx.doi.org/10.1177/1745691612442904 